of the earth's history. He correlated the predominance of Cryptogams with the Primary epoch, of Gymnosperms with the Secondary, and of Angiosperms with the Tertiary. The discoveries of the half century that have elapsed since Brongniart published his views have confirmed the broad truth of his generalisations. Recently they have been expounded and illustrated by one who worthily follows his illustrious countryman in this particular field of study,--by the Comte de Saporta in the preface to his Tertiary Flora of the South of France.

Accepting this classification, which is so far both systematic and stratigraphical, Prof. Balfour prepares the student for dealing with the more obscure fossil remains by introducing each epoch with a résumé of the leading characters of the great group of plants which are found in it, drawn from their living representatives. The fossils characteristic of the various formations then follow in detail. The most recent observations are given. Look, for example, at the illustrations and descriptions of the fructification of the Cryptogamic plants of the Coal measuresthe ferns, club-mosses and mares-tails-brought together here for the first time.

The numerous woodcuts and the admirable plates greatly enhance the value of the volume.

WM. CARRuthers

\section{THE BRTTISH MUSEUM PHOTOGRAPHS}

Photographs from the Collections of the British Museum. Taken by S. Thompson. ist Series. (London: W. A. Mansell and Co.)

MONG all the varied purposes to which the art of
photography has been applied, there is perhaps
none for which it has proved itself more valuable than for
the reproduction of ancient works of art. It matters not
whether it be the sublime conception of some ancient
Greek sculptor, the thorny-looking inscription on a
Babylonian brick, or the stone hatchet of some pre-
historic troglodyte, in each case the reproduction by the
camera, if executed by a competent operator, will give a
more vivid and faithful idea of the original than any
drawing by however skilful an artist. In the case of inscriptions, of minute patterns, of delicacy of form, or of the distinctive character of an object, the merely mechanical process, though not entirely without its drawbacks, possesses a great advantage over the skilful artist, inasmuch as it is entirely free from prejudice. The artist, however conscientious, is always prone to draw incorrectly such details as he does not understand, and to attempt some improvement in force and effect in those which he fully appreciates. It is only in the case of coins and of other small objects which it is necessary to hold in more than one light in order fully to discern the details, that a good drawing is preferable to a photograph ; and then the question arises, what is a good drawing?

For rendering available to students the contents of a museum, photography is invaluable. By it the objects which, in many instances, it is impossible to study at leisure in their repository, are, as it were, rendered portable, and made available for extended examination at home, and for reference at a moment's notice. It is with great satisfaction, therefore, that we see this series of nearly a thousand quarto photographs of objects in our national collections issued to the public by Messrs. Mansell and Co. It is divided into seven parts-ethnographical and pre-historic, Egyptian, Assyrian, Grecian, Etruscan and Roman, Mediæval, and Seals, and one great advantage to the student is that he is by means of a comprehensive catalogue enabled to make his own selection of such photographs as come within his own particular province.

That the choice of the objects to be photographed has been judicious may be inferred from the fact that it has been made by the aid of Dr. Birch, Mr. Charles Newion, Mr. A. W. Franks, Mr. Murray, Mr. George Smith, and Mr. Walter de Gray Birch, all well known for their labours in the departments which they represent. Four of these gentlemen have also prepared the catalogue.

The photographs themselves are remarkably well and clearly executed, the figures in all cases being sufficiently large to make the details visible. We have but one fault to find, which it is to be hoped may be easily remediedthe absence of any scale on the photographs, and of any dimensions in the catalogue. In the case of some of the pre-historic and ethnographical objects it would also be an advantage if further particulars were given as to the localities from which they were obtained.

The catalogue is accompanied by an interesting introduction from the pen of Mr. Charles Harrison, giving a good general view of the progress of human civilisation, which the objects photographed illustrate, and also giving the rationale of the whole series. We cordially concur in his hope that each local museum will have its objects photographed, and that the plates like these may be made accessible to the public at a fixed moderate cost. In the meantime we commend these illustrations of our rich national collection to the readers of NATURE.

\section{OUR BOOK SHELF}

Autumns on the Spey. By A. E. Knox, M.A., F.L.S. Author of "Ornithological Rambles in Sussex, \&c. (London: Van Voorst.)

WE have seldom come across a book in which the dulce and the utile, science and amusement, are so happily combined as in the modest little volume before us. $\mathrm{Mr}$. Knox's main object, apparently, in spending his autumn on the Spey, was to fish for salmon in that trying river; and some of his wonderful achievements in this exciting occupation are narrated in an almost fascinating, and certainly unpretentious manner, in a few of the chapters of his booklet. But it would be a great mistake to consider this merely a book of sport, and Mr. Knox nothing more than a genial "piscator ", he has already proved what is confirmed by this his most recent work, that his knowledge of British zoology, and especially ornithology, is extensive and thorough. To any one who desires to see the report of a trained and patient observer on the zoology, and even geology, of the basin of the Spey and and of contiguous districts, we would with confidence recommend Mr. Knox's work. It contains much that is valuable and interesting on these subjects, and a good deal that is new to many. Quite charming and very curious is his account of the modus operandi of a family of crossbills (Loxia curvirostris) which he watched while standing under a tree, a few inches above his head, busily engaged at their marvellous employment of splitting the 